\title{
Female Teachers' Participation in School Management in Bale Zone Sinana Woreda
}

\author{
Yosef Hailu (MA, Lecturer) \\ Madawalabu University, P.o.box 247, Ethiopia
}

\begin{abstract}
The study was aimed at assessing the actual practices and problems of female teachers' participation in managerial positions of schools' in Bale Zone Sinana Woreda.

The research worker was guided by the following four leading questions: What are the causes of low participation of female teacher in school administration? To what extents is the severity of the disparity of female teachers? What are the institutional, social and cultural factors that influence their participation in school management? What are the major solutions to be taken?

Data were collected from WEO officials, female teachers, principals and supervisors through questionnaire and interview. Based on the data gathering from these respondents presentations, analysis and interpretation was made and listed in percentage and ranks in orders.

So from the study, majority of the respondents confirmed that female teachers' participation in school management was very low. The finding showed for this to happen: being over burdened with home responsibility, influences of socio-cultural and institutional factors, lack of acceptance by school communities and society and lack of interest and commitment were the major ones.

However, majority of respondents confirmed that females haven't less ability when compared to their male counter parts in their opinion towards female effectiveness in managerial position.

The following recommendation forwarded as a remedy: providing a special quota while recruiting and selecting for school leadership positions, encouraging female teachers by refining selection criteria for training and give priority for them and provide continuous short and on-time trainings to enhance their competencies and up-date their point of understanding in each aspect.
\end{abstract}

Key terms: gender parity, leadership, social-cultural factors

DOI: $10.7176 / \mathrm{JRDM} / 56-01$

Publication date: June $30^{\text {th }} 2019$

\author{
Abbreviation \\ EdPM- Educational Planning and Management \\ TTI- Teacher Training Institute \\ WEO-Woreda Educational Bureau
}

\section{Introduction}

\subsection{Background of the Study}

Women are essential human resource in different activities; they should be treated to get equal opportunities as men in all fields of social aspects especially in the education system that enables them to act role model.

No doubt that education is a vehicle of rights where one can gain skills, experience, knowledge and other related basic life improvements. In this regard females are the primary basis of education for the success of socio economic progress. But they are deprived of these rights. There are factors which disabled women from different developmental and labor positions; some are traditional proverbs, sex role stereotypes and sexual harassment which tied them not to get into power. As Sullerot $(1977,92)$ explained women who stay at home are still considered to be a morally right while those who got out side even to work are disapproved such an attitude hinder women's participation to come to the leadership program indifferent social and economical sectors especially in education system.

Moreover scholars point out that women are important human resource and when they are out of administrative tasks, the schools are missing the vital inputs of women could contribute their unique strength and perspectives to the organization (Sekran, 1992, 65).

Therefore economic development is unthinkable without active participation of females in different developmental agendas. However, today in Ethiopia women haven't been able to equally benefit from the nation's wealth and decision making agenda due to their low participation in the economy and management position (ETP, 1986). At all educational levels of the country there were many problems which hinder functional participation of female teachers in the management system of Ethiopian schools Thus, the study tried to identify the factors and put recommendation to maximize women teachers' participation in the school administration system.

This research work was conducted in Oromia regional state, Bale zone specifically in Sinana Woreda 
Primary Schools.

\subsection{Objective of the Study}

\subsection{General objective}

The general objective of this study is to investigate factors that are affecting the participation of female teachers in school management in Bale Zone Sinana Woreda Primary Schools and presenting some possible alleviating mechanisms for each draw backs.

\subsection{Specific objectives}

The specific objectives of the study are the following:-

1. To identify the root causes of the problem

2. To assess the history of female teachers educational background in the Woreda in light of the current cultural, social and institutional aspects of education.

3. To investigate the severing factors that hinder female teachers' participation in school management.

4. To suggest some possible solutions to the problem.

\section{Research Design and Methodology}

\subsection{Methods of the Study}

A descriptive survey research method was employed, because it is appropriate for analyzing facts and treating the existing conditions of the schools system at large.

\subsection{Sample and Sampling Techniques}

The sampling technique that is used to select the desired sample is simple random sampling method.

Based on the method the following samples selected from the population: 7 woreda educational (out of 19) experts 52 female teachers (from 60 schools), 20 principals (out of 60), and 5 supervisors (out of 15).

\subsection{Data Collecting Tools}

The following tools were used to collect the necessary information for the research: interview and questionnaire were developed for Woreda educational heads and experts, female teachers, school principals and supervisors.

\subsection{Methods of Data Analysis}

The method of data analysis is a mixed approach both qualitatively and quantitatively. Tables and percentage used to analyze quantitatively whereas similar thematic ideas were analyzed qualitatively based on the information gained.

\section{Presentation, Analysis and Interpretation}

This chapter comprised of two parts. Part one deals with the characteristics of the sample populations and their analysis in terms of sex, age, qualification, professional training and service year. The second major part deals with the presentation and analysis of the data gathered through questionnaire and interview from, WEO head, WEO experts, female teachers, principals and supervisors. 
Table 1. Characteristics and Classification of the Respondents

\begin{tabular}{|c|c|c|c|c|c|c|c|c|c|c|c|c|}
\hline \multirow{3}{*}{ №.. } & \multirow{3}{*}{\multicolumn{2}{|c|}{$\begin{array}{c}\text { Varieties of Characteristics and } \\
\text { Classifications }\end{array}$}} & \multicolumn{10}{|c|}{ Respondents } \\
\hline & & & \multicolumn{2}{|c|}{$\begin{array}{l}\text { WEO } \\
\text { head }\end{array}$} & \multicolumn{2}{|c|}{$\begin{array}{l}\text { WEO experts } \\
\text { (officials) }\end{array}$} & \multicolumn{2}{|c|}{$\begin{array}{l}\text { Female } \\
\text { teachers }\end{array}$} & \multicolumn{2}{|c|}{ Principal } & \multicolumn{2}{|c|}{ Supervisor } \\
\hline & & & No. & $\%$ & No. & $\%$ & No. & $\%$ & No. & $\%$ & No. & $\%$ \\
\hline \multirow[t]{3}{*}{1} & \multirow[t]{3}{*}{ Sex } & Male & 1 & 100 & 4 & 66.7 & - & - & 18 & 90 & 5 & 100 \\
\hline & & Female & - & - & 2 & 33.3 & 52 & 100 & 2 & 10 & - & - \\
\hline & & Total & 1 & 100 & 6 & 100 & 52 & 100 & 20 & 100 & 5 & 100 \\
\hline \multirow[t]{4}{*}{2} & \multirow[t]{4}{*}{ Age } & $20-30$ & 1 & 100 & 3 & 50 & 11 & 21.2 & 6 & 30 & 1 & 20 \\
\hline & & $31-45$ & - & - & 2 & 33.3 & 41 & 78.8 & 14 & 70 & 4 & 80 \\
\hline & & Above 46 & - & - & 1 & 16.7 & - & - & - & - & - & - \\
\hline & & Total & 1 & 100 & 6 & 100 & 52 & 100 & 20 & 100 & 5 & 100 \\
\hline \multirow[t]{4}{*}{3} & \multirow[t]{4}{*}{ Qualification } & $12+\mathrm{TTI}$ & - & - & 1 & 16.7 & - & - & - & - & - & - \\
\hline & & Diploma & - & - & 1 & 16.7 & 52 & 100 & 19 & 95 & 4 & 80 \\
\hline & & B.A & 1 & 100 & 4 & 66.7 & - & - & 1 & 5 & 1 & 20 \\
\hline & & Total & 1 & 100 & 6 & 100 & 52 & 100 & 20 & 100 & 5 & 100 \\
\hline \multirow[t]{4}{*}{4} & \multirow{4}{*}{$\begin{array}{l}\text { Professional } \\
\text { training }\end{array}$} & EdpM & - & - & 2 & 33.3 & - & - & 1 & 5 & - & - \\
\hline & & Non-educational & - & - & 1 & 16.7 & - & - & - & - & - & - \\
\hline & & $\begin{array}{l}\text { Trained as } \\
\text { teaches }\end{array}$ & 1 & 100 & 3 & 50 & 52 & 100 & 19 & 95 & 5 & 100 \\
\hline & & Total & 1 & 100 & 6 & 100 & 52 & 100 & 20 & 100 & 5 & 100 \\
\hline \multirow[t]{5}{*}{5} & \multirow{5}{*}{$\begin{array}{l}\text { Service on } \\
\text { year }\end{array}$} & 1-10 Years & - & - & 3 & 50 & 17 & 32.7 & 7 & 13.5 & 2 & 40 \\
\hline & & $11-20$ years & 1 & 100 & 2 & 33.3 & 31 & 59.6 & 39 & 75 & 3 & 60 \\
\hline & & 21-30 years & - & - & 1 & 16.3 & 4 & 7.7 & 6 & 11.5 & - & - \\
\hline & & Above 30 years & - & - & - & - & - & - & - & - & - & - \\
\hline & & Total & 1 & 100 & 6 & 100 & 52 & 100 & 52 & 100 & 5 & 100 \\
\hline
\end{tabular}

As expressed in table 1 from all classification of respondent from the point of profession only one principal is assigned with the right professional preparation. This implies that majority of the respondents were trained with teaching profession but not in management disciplinary fields. This may influence the quality of educational management system. Because they are not equipped with the needed professional attributes of management activities.

With respect to year service all of the respondents are served below 20 years and they are trained within the proclamation of the ETP (1994), they are adjusted with the programs of the current system. So they would have the potential practice what is intended in the educational system. 
Table 2. Extent of Female Teachers Participation in Education Management

\begin{tabular}{|c|c|c|c|c|c|c|c|c|c|c|c|}
\hline \multirow{3}{*}{ No } & \multirow{3}{*}{ Items } & \multicolumn{10}{|c|}{ Respondents } \\
\hline & & \multicolumn{2}{|c|}{$\begin{array}{l}\text { WEO } \\
\text { head }\end{array}$} & \multicolumn{2}{|c|}{$\begin{array}{l}\text { WEO experts } \\
\text { (officials) }\end{array}$} & \multicolumn{2}{|c|}{$\begin{array}{l}\text { Female } \\
\text { teachers }\end{array}$} & \multicolumn{2}{|c|}{ Principal } & \multicolumn{2}{|c|}{ Supervisor } \\
\hline & & No. & $\%$ & No․ & $\%$ & No. . & $\%$ & No. & $\%$ & №. & $\%$ \\
\hline \multirow[t]{5}{*}{1} & $\begin{array}{l}\text { The extent of female teachers } \\
\text { participation in school management }\end{array}$ & & & & & & & & & & \\
\hline & A. High & - & - & - & - & - & - & - & - & - & - \\
\hline & B. Low & 1 & 100 & 2 & 33.3 & - & - & - & - & - & - \\
\hline & C. Very low & - & - & 4 & 66.7 & 52 & 100 & 20 & 100 & 5 & 100 \\
\hline & D. Total & 1 & 100 & 6 & 100 & 52 & 100 & 20 & 100 & 5 & 100 \\
\hline \multirow[t]{5}{*}{2} & $\begin{array}{l}\text { The degree of female teachers' } \\
\text { participation in school management } \\
\text { compared to male teachers. }\end{array}$ & & & & & & & & & & \\
\hline & A. High & - & - & - & - & - & - & - & - & - & - \\
\hline & B. Low & - & - & - & - & - & - & - & - & - & - \\
\hline & C. Very low & 1 & 100 & 6 & 100 & 52 & 100 & 20 & 100 & 5 & 100 \\
\hline & D. Total & 1 & 100 & 6 & 100 & 52 & 100 & 20 & 100 & 5 & 100 \\
\hline \multirow[t]{6}{*}{3} & $\begin{array}{l}\text { Reasons for low participation of } \\
\text { female teachers on educational } \\
\text { management }\end{array}$ & & & & & & & & & & \\
\hline & A. Social factors & - & - & 1 & 16.7 & 19 & 36.5 & 7 & 35 & 1 & 20 \\
\hline & B. Instructional factors & - & - & 1 & 16.7 & 6 & 11.5 & 4 & 20 & - & - \\
\hline & $\begin{array}{l}\text { C. Lack of interests and absence of } \\
\text { acceptance by the school } \\
\text { community }\end{array}$ & 1 & 100 & 4 & 66.7 & 25 & 51.9 & 9 & 45 & 4 & 80 \\
\hline & D. In ability to show responses & - & - & - & - & - & - & - & - & - & - \\
\hline & Total & 1 & 100 & 6 & 100 & 52 & 100 & 20 & 100 & 5 & 100 \\
\hline
\end{tabular}

As observed from table 2, item 1 depicts the response of respondents on the extent of female participation in educational management $4(66.7 \%)$ of WEO experts, $52(100 \%)$ of female teachers, $20(100 \%)$ of principals and $5(100 \%)$ of supervisors replied as very low. It can be deduced that female teachers' participation in school management is very limited.

Item two of table 2 depicts 1 of WEO head, 6(100\%) of WEO officials, 52(100\%) of female teachers, $20(100 \%)$ of principals $5(100 \%)$ of supervisors replied that female teachers' participation in school management was very low. The majority respondents responded in their open ended questionnaires almost all of the school management in primary schools were hold by males. This implies that the problem of culture was associated and management of females yet not improved.

Item three of the same table shows; 1 of WEO head, $4(66.7 \%)$ of WEO officials, $27(51.9 \%)$ of female teachers, $9(45 \%)$ of principals, and $4(80 \%)$ of supervisors replied that the problem was not only lack of interest to the program from female teachers themselves it is but also absence of acceptance from the community. Most of respondents agreed that lack of interest and absence of acceptance by the community made great implement for female teachers to be involved in managerial tasks of schools. 
Table 3. Female Teacher's Participation and Aspiration for Educational Management

\begin{tabular}{|c|c|c|c|c|c|c|c|c|c|c|c|}
\hline \multirow{3}{*}{ №. } & \multirow{3}{*}{ Items } & \multicolumn{10}{|c|}{ Respondents } \\
\hline & & \multicolumn{2}{|c|}{$\begin{array}{l}\text { WEO } \\
\text { head }\end{array}$} & \multicolumn{2}{|c|}{$\begin{array}{l}\text { WEO experts } \\
\text { (officials) }\end{array}$} & \multicolumn{2}{|c|}{$\begin{array}{l}\text { Female } \\
\text { teachers }\end{array}$} & \multicolumn{2}{|c|}{ Principal } & \multicolumn{2}{|c|}{ Supervisor } \\
\hline & & No. & $\%$ & No. & $\%$ & №. & $\%$ & No. & $\%$ & №. & $\%$ \\
\hline \multirow[t]{4}{*}{1} & $\begin{array}{l}\text { Lack of role models of female } \\
\text { teachers in educational management } \\
\text { limited the aspiration of them to } \\
\text { participate in educational } \\
\text { management }\end{array}$ & & & & & & & & & & \\
\hline & A. Agree & 1 & 100 & 4 & 66.7 & 52 & 100 & 20 & 100 & 5 & 100 \\
\hline & B. Disagree & - & - & 2 & 33.3 & - & - & - & - & - & - \\
\hline & C. Total & 1 & 100 & 6 & 100 & 52 & 100 & 20 & 100 & 5 & 100 \\
\hline \multirow[t]{4}{*}{2} & $\begin{array}{l}\text { In adequate training opportunities } \\
\text { hinder the participation of female } \\
\text { teachers in educational management }\end{array}$ & & & & & & & & & & \\
\hline & A. Agree & 1 & 100 & 5 & 83.33 & 52 & 100 & 20 & 100 & 5 & 100 \\
\hline & B. Disagree & - & - & 1 & 16.67 & - & - & - & - & - & - \\
\hline & C. Total & 1 & 100 & 6 & 100 & 52 & 100 & 20 & 100 & 5 & 100 \\
\hline \multirow[t]{4}{*}{3} & $\begin{array}{l}\text { Lack of priority to assign principals } \\
\text { at near urban area influence their } \\
\text { participation in management of the } \\
\text { education system }\end{array}$ & & & & & & & & & & \\
\hline & A. Agree & 1 & 100 & 5 & 83.33 & 52 & 100 & 15 & 100 & 5 & 100 \\
\hline & B. Disagree & - & - & 1 & 16.67 & - & - & 5 & - & - & - \\
\hline & C. Total & 1 & 100 & 6 & 100 & 52 & 100 & 20 & 100 & 5 & 100 \\
\hline \multirow[t]{4}{*}{4} & $\begin{array}{l}\text { Lack of quota to select and } \\
\text { recruitment of female teachers } \\
\text { hinder the deployment of themselves } \\
\text { on educational management }\end{array}$ & & & & & & & & & & \\
\hline & A. Agree & 1 & 100 & 5 & 83.33 & 52 & 100 & 17 & 100 & 5 & 100 \\
\hline & B. Disagree & - & - & 1 & 16.67 & - & - & 3 & - & - & - \\
\hline & C. Total & 1 & 100 & 6 & 100 & 52 & 100 & 20 & 100 & 5 & 100 \\
\hline
\end{tabular}

Table 3, item one is focused on the importance of role model present in school and other educational institutions on management programs. Someone can observe from the table, 1 of WEO head, 4(66.7\%) WEO officials, 32 of female teachers, $20(100 \%)$ of principals and $5(100 \%)$ of supervisors replied that lack of role models of female teachers in educational management was highly influential component on the aspiration of female teachers to participate in school management.

In contrary to the response justified above $2(33.3 \%)$ of WEO officials replied that lack of role models for females on educational management was not affect them to participate in school management. But majority of the respondents are stronger with this idea. This infer, almost all respondents data seem strongly agreed with the theory "Lack of opportunities for women to see other women in administrative position, to observe how those women just steps ahead of them is one potential hindrance for women aspiration to managerial roles" (Bernstein, B. E. and Grambs, J., 1976).

Item two of the same table asserted that whether lack of training opportunities impact female teachers participation towards school management or not. As observed from the table 1 of WEO head, 5(83.3\%) of WEO officials, $32(100 \%)$ of female teachers, and $20(100 \%)$ of principals and $5(100 \%)$, supervisors reported that inadequate training opportunities hinders participation of female teachers in educational management where as $1(16.6 \%)$ of WEO officials has disagreement with this idea.

This implies that the majority of respondents examined the continuity of training opportunities make female teachers active to involve in management position. In respect to this the UNESCA (1996:57-60) examined that "Unequal access to education and training might be the causes for the choice of discipline that would determined the women for the occupation".

Item three of this table showed that lack of given priority to assigned teachers (Principals of Supervisors) in schools regarding to distance and availability of infrastructures.

1 of WEO head, 5(83.3\%) of WEO officials, 52(100\%) female teachers, $15(75 \%)$ principals and 5(100\%) of supervisors agreed on lack of priority to assigned female principals (supervisors) at distant are influence them to participate in educational management. 
Whereas $1(16.77 \%)$ of WEO officials and $5(25 \%)$ of principals viewed that it was not influential. These data implied that majority of principals, supervisors, female teachers, WEO officials and head master asserted that distance of school was very influential for female teachers' participation in school management.

Depending on the current trend and experiences which have been observed in the real world enforced the student researcher to conclude that, the proximity of schools and well equipped with infrastructures enhance females to be deployed in school management actively and to have had positive aspiration.

The last item, in the same table depicted that whether absence of special quota to select and recruitment of female teachers hinders them to the deployed as educational managers or not. The data showed that 1 of WEO head, $5(83.33 \%)$ of WEO officials, $52(100 \%)$ of female teachers, $17(85 \%)$ of principals and $5(100 \%)$ of supervisors agreed that the lack of quota to select and recruitment female teachers hinder them from active deployment in educational management. This implied that majority of respondents replied that special quota is an important for selecting and recruitment of female teachers to come in to school's management position.

Table 4. Strategies for Enhancing Female Teachers' Participation in School Management

\begin{tabular}{|c|c|c|c|c|c|}
\hline \multirow{3}{*}{ №. } & \multirow{3}{*}{ Items } & \multicolumn{4}{|c|}{ Respondents } \\
\hline & & \multicolumn{2}{|c|}{$\begin{array}{l}\text { WEO } \\
\text { head }\end{array}$} & \multicolumn{2}{|c|}{$\begin{array}{l}\text { WEO experts } \\
\text { (officials) }\end{array}$} \\
\hline & & No. & $\%$ & No. & $\%$ \\
\hline \multirow[t]{5}{*}{1} & $\begin{array}{l}\text { Official strategies put in place by the WEO head and officials to make } \\
\text { female teachers active participant in educational management }\end{array}$ & & & & \\
\hline & A. Satisfactory & - & - & - & - \\
\hline & B. Moderate & - & - & 2 & 33.3 \\
\hline & C. Unsatisfactory & 1 & 100 & 4 & 66.7 \\
\hline & D. Total & 1 & 100 & 6 & 100 \\
\hline \multirow[t]{5}{*}{2} & $\begin{array}{l}\text { In your opinion what should be done for alleviating the problems that are } \\
\text { affecting female teachers' participation in the management of schools }\end{array}$ & & & & \\
\hline & A. Creating continuous functional training & 1 & 100 & 3 & 50 \\
\hline & $\begin{array}{l}\text { B. Psychological advancement for female teachers to be motivated } \\
\text { and participated }\end{array}$ & - & - & 2 & 33.33 \\
\hline & C. Enhancing professional awareness programs & - & - & 1 & 16.67 \\
\hline & D. Total & 1 & 100 & 6 & 100 \\
\hline
\end{tabular}

As illustrated in item 1 of table 4 majority respondents, that is 1 of the WEO head, and 4(66.7\%) of WEO officials replied as unsatisfactory and only $2(33.3 \%)$ of the WEO officials replied as moderate on the strategies to be enhanced for the sake of females participation in school management. It implies that there were not functional and practical strategies to put in place for the advancement of female teachers participation in school management.

Item 2 of the same table depicts that 1 of WEO head, and 3(50\%) of WEO officials ascertained on creating continuous functional training as a crucial measure. $2(33.33 \%)$ of the WEO officials would ascertained that on that of psychological advancement tactics and 1(16.67\%) of WEO officials responded that enhancement professional awareness agendas are important.

Even though, majority of the respondents asserted that trainings is a crucial measure for advancing female participation in school management, but psychological advancement and professional awareness programs had to practice side by side as supplementary programs for the training, which is conducted for the advancement of female teachers managerial capacities.

This is a summary of the most important reaction of the respondents to the questions raised in both the interview and the questionnaire towards the management of female teachers in primary schools. According majority of the respondents listed the following of major problematic issues.

- $\quad$ Lack of appropriate capacity on part of in built school management

- Unfair systems in assigning of school principals

- $\quad$ Lack of confidence

- Social and institutional factors

- Discrimination, prejudice and disparity

- Lack of proper coordination and sharing their experience with other in the staff

- Lack of transparency regarding promotion and other benefits. Respondents were also asked to suggest what measures should be taken to improve the participation of female teachers in school management.

Majority of them have responded as follow:-

- The chances of giving priority for training for females on managerial positions should be highly practiced and females should also be encouraged.

- Female teachers should give opportunities to practice leadership roles at different managerial levels like 
that of department head, unit leader and etc.

- There should be experience sharing session by which the works of role model school managers introduced to others.

- Designing equity in all aspects of educational management posts, so that women needed to be encouraged and to apply and compact to the position.

\section{Summary, Conclusion and Recommendation}

\subsection{Summary}

The study was aimed at assessing the actual practices and problems of female teachers' participation in managerial positions of schools' in Oromia Region, Bale Zone Sinana Woreda.

The research worker was guided by the following four leading questions:-

1. What are the causes of low participation of female teacher in school administration?

2. To what extents is the severity of the disparity of female teachers?

3. What are the institutional, social and cultural factors that influence their participation in school management?

4. What are the major solutions to be taken?

Furthermore, necessary conceptual and theoretical background of the research though relevant to the topic under study had been secured by reviewing the related literatures to the problems. Data were collected from WEO head through interview, officials, female teachers, principals and supervisor. Based on the data gathering from these respondent presentations, analysis and interpretation was made and listed in percentage and ranks in orders.

\section{Short Summary of the Findings}

1. With regard to the extent of female teachers in school management the majority of the respondents $4(66.7 \%)$ of WEO officials, 52(100\%) of female teachers, $20(100 \%)$ of principals and $5(100 \%)$ of supervisors confirmed that female teachers' participation in school management was very low.

2. With regard to factors affecting female teacher's involvement in school management: Majority of the respondents find out.

a) Being over burdened with home responsibility.

b) Due to socio-cultural and institutional factors influences

c) Lack of access for involvement

d) Lack of acceptance by school communities and society.

e) Lack of interest and commitment

3. As indicated by the majority of respondents 1 of woreda head, 4(66.7\%) of WEO officials, 52(100\%) of female teachers, 20)100\%) of principal and 5(100\%) of supervisors ascertained that presence of female role models in educational management highly increased the aspiration of female teachers towards their participation in school management.

4. With regard to female effectiveness in managerial position, majority of respondents confirmed that females have not less ability when compared to their male counter parts.

5. With regard to effort made to enhance female teachers to be involved in educational management, as ascertained by majority of WEO head and officials, there were not functional activities to be practiced.

\subsection{Conclusions}

Based on the findings of the study, the following conclusions could be drawn.

1. As the result of this study disclosed, extent of female teacher's participation in school management in which this study conducted was very low. The degree of range between male and female principals and vice principals were significantly very wide.

2. Strategies for enhancing of female teachers participation in school management were very important. However, educations organization failed to fill the widest gap between both sex groups on management positions.

3. Even though different policies and programs are designed and formulated about females all over participation in different social, political and economical positions. There had not been significant change yet. Because there are many factor that contributed to undermine the participation of females in primary school, management. Some of them are:-

- Socio-cultural influences

- Lack of access and community acceptance

- Lack of commitment from the point of themselves and others

- Lacks of special quota and in adequate training and etc ... are the major cases that highly influenced female teachers to participation in school management. 


\subsection{Recommendation}

There is a need to increase women representation in educational management in all levels of the system in the country. The minority of education should encourage women to accept positional in different leadership positions up to the school level, (Unit leader, Department head, Club leader and other).

Depend on the findings and the conclusions of the study and the government declarations the following recommendations were made so that they may help to minimize the problems that were influenced female teachers to participate them in school management in Bale Zone Sinana Woreda.

1. The finding of this study supplemented by literatures of other scholars pointed out that participation of females in educational management would have great in pact on the total teaching learning process as well as on the overall social, cultural and economical development. Therefore, in order to alleviate the factors that limit their participation, efforts should be made. With respect to this:-

I. Woreda Education Office should be:-

a) Provided special quota while recruitment and selecting school positions leaders (supervisors, principals, vice principals and other positions with the profession).

b) Encourage female teachers by refining selection criteria for training and give priority for them.

c) Encouraging female teachers to increase their motivation and commitment.

d) Provide continuous short and on-time trainings to enhance their competencies and up-date their point of understanding in each aspect.

e) Giving priority in time of assigning in different positions.

II. The School administrations should also be assigned female teachers in leadership positions of the school (Unit leader, Department heads, Club leader, Forum coordinator and etc) to build their capacity of management.

2. Although female principals in the study are said to be less competent, special consideration should be given in line with the identified draw backs that faced females due to different point of angles. Long and short term training programs should be design at regional level to up-grade their qualification and to-up date their point of understanding and awareness trainings in woreda and school level must be practiced based on the gaps observed in their actual experi4ences and performances.

3. Even though, the government made a continuous effort to overcome the problems which have obstacles females to participate in school management and decision making programs. Still it couldn't do functional achievement as intended. Thus, to alleviate, such problems the following measures should be taken:-

I. Woreda Education Office should be:-

a) Design effective professional support and made qualified supervisor to provide professional support for female teachers and school principals and supervisors.

b) Designing clear transparency or pro-active information concerning females on their promotion and other benefits.

II. Female teachers should create different meetings in school and discuss on the issues of:-

- Women's commitment

- Sex discrimination

- Gender disparity

- Equity in management position

- Equity of up-grading their qualification

III. Government policy formulated regarding gender equity should be implemented in any level of educational institutions by the concerned body.

IV. Attention and special support should be given in WEO and school levels for those females, who want to be leaders, as they were models.

V. Continuing leadership training programs should be designed and practiced in regional zone, woreda and school levels for enhancing female's leadership approaches as much as possible.

\section{References}

Bernstein, B. E. and Grambs, J. (1976), Sex and academic field in relation to birth order and achievement. Psychological Repor ts

ETP (1994), Education and Training Policy. Addis Ababa.

Sekaran, U. (1992). Research Methods for Business: A skill building

Sekaran, U. (1992), "Middle-class Dual-earner Families and their Support Systems in Urban India"

Sullerot (1974) Woman, Society and Change, McGraw Hill

UNECA, (1996). "A Study of the Economic Empowerment of Women and their Role in the Socio-economic Development of Africa" Addis Ababa (Unpublished). 


\section{Acknowledgment}

I give my first and for most gratitude to my family for their invaluable support during the work of this study.

Lastly I wish to tank Sinana Woreda Education Office Head and other officials, School Principals, Cluster Supervisors and female teachers for their commitment in filling the questionnaires and providing the necessary information as needed.

"The study, my original work, has not been presented in any other institutions and that all sources of material used for the research have been duly acknowledged"

Yosef Hailu

Researchers' Name
Signature 